\title{
The opinions of students, professors and practice teachers on the teaching practice course
}

\author{
Esra Töre \\ Department of Education Science, İstanbul Sabahattin Zaim University, Turkey
}

\begin{tabular}{l} 
Article Info \\
\hline Article history: \\
Received Oct 17, 2019 \\
Revised Nov 7, 2019 \\
Accepted Jan 3, 2020 \\
\hline
\end{tabular}

Keywords:

Guidance

Psychological counseling

Teaching practice

\begin{abstract}
The goal of this study was the evaluation of the teaching practice course in the Psychological Counseling and Guidance (PCG) department by students, professors and practice teachers. It was a pneumology study designed with qualitative research method. The study group consists of seven students, five professors and five practice teachers from 3 different schools and 3 different universities in İstanbul. Study data were analyzed with content analysis. It was found that the communication and collaboration between the professors and practice teachers of the teaching practice course were low, and the applications within the scope of the course were inadequate. Additionally, the study has revealed that it is necessary to inform the practice teachers about the previous courses and internships the students have taken, to ensure the attendance of students to full-day practice courses on different days and that a detailed teaching practice course guide is prepared. This study is thought to benefit the literature in the sense that it shows how PCG teaching practice course differs from other teaching practice courses, in addition to suggestions to the decision makers and practitioners for improving the course.
\end{abstract}

This is an open access article under the CC BY-SA license.

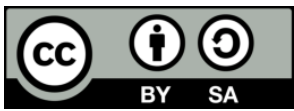

\section{Corresponding Author:}

Esra Töre

Department of Education Science, İstanbul Sabahattin Zaim University, 34303, Küçükçekmece, İstanbul, Turkey.

Email: esra.tore@izu.edu.tr

\section{INTRODUCTION}

Education is among the primary concerns of societies. Improving the quality of education is closely related to training qualified teachers. The rapidly changing and developing conditions of the 21 st century necessitate that quality training is given to teachers in the faculties of education, as well as improving the experience, knowledge and skills of the teacher candidates by providing the required means and support in the practice schools [1].

Practical applications in the pre-service teacher training programs have strategic importance, because theoretical knowledge can only be implemented via application. Practical applications allow the candidates to know the profession they are preparing for and provide a chance for them to meet the real world. In this regard, teaching practice applications must be planned and implemented in a serious manner $[2,3]$. Teaching practice courses allow the students to get acquainted with their professions and provide them opportunities to put into practice the theoretical knowledge that they have learned [4]. The teacher training system in Turkey follows a policy that is heavy on the theoretical side and fails to establish a connection between theory and practice. "School Experience" and "Teaching Practice" are the primary practice courses with high credit in the undergraduate programs on teacher training [5]. However, the studies point to 
the many problems in these practice-based courses. Said studies have found problems in the practice courses such as that the students are given poor counsel by their teachers, the teachers give inadequate feedback, a correct course planning cannot be made because the course durations are short, practice schools and teachers are chosen poorly, other stakeholders give little guidance to teacher candidates and poor assessments [5-9]. The teaching practice course allow the practice students to be better prepared for the profession of teaching and to gain the proficiency to use the general and field knowledge that they receive during their training as well as their knowledge, skills, attitudes and behaviors about the profession of teaching in private and public educational institutions under the Ministry of National Education (MNE).

The Directive on Teaching Practice [10] mentions two primary actors to conduct the process of practice. These actors are the Professors and the Practice Teachers. A professor is responsible for planning the teaching practice courses together with the practice teachers, preparing the practice students for the implementation of the course, visiting the practice students in the school at least 4 times during a semester and monitoring their progress, providing feedback on the applications and conducting assessment on the MNEIS (Ministry of National Education Information System). The practice teacher, is charged with providing guidance to the student in planning and implementing the practices; monitoring, assessing and giving feedback to the students at least 4 times during a semester, and entering the scores to the MNEIS. The responsibilities of the practice students, on the other hand, are adhering to the rules which must be followed by the teachers, implementing and reporting the applications during the time they spend in the educational institution. [10,11].

Ellis [12] mentions the "school-based teacher education process" in her article where she discusses the problems of teacher education in England. The model in question is similar with the model in Turkey. On one side of the model is the mentor school teacher who provides practical support and guidance, and on the other side is the academician from the university who offers research-based knowledge and perspective. The teacher candidate finds the opportunity to test his/her own hypotheses, conduct practical application and learn by practice. Smith and Souviney [13], in their qualitative study where they attempt to evaluate the achievements of teacher candidates during internships, have found that; (a) $75 \%$ of the students are in the collaborative group during internships and learn to design the courses in a "student-centered" way, (b) realize how to solve problems when they encounter them, (c) can see the problems other than the daily matters of the class, and (d) can better understand the individual circumstances that affect the school performance of the students.

Gökulu [1] has found that advisory teachers must provide more support to teacher candidates during the process in subjects like filling the necessary forms, preparing teaching plans, preparation for the class and evaluation. Roughly $30 \%$ of the teacher candidates see the teaching practice course as the most influential course in providing the necessary skills for teaching, while $70 \%$ of the teacher candidates view other courses more important. The functionality of the teaching practice course for providing the necessary professional skills is seen as "moderate" by teacher candidates, "high" by practice teachers and "moderate" by professors.

Practice Courses in the Psychological Counseling and Guidance (PCG) Departments were initiated by the Council of Higher Education (CoHE) [14] starting from the 2007-2008 academic year, establishing a license program to be conducted in these departments. The practice course subjects were as follows (semesters written between parentheses): observation in schools (3), professional guidance and psychological counseling practice (6), field study in guidance and psychological counseling (8) and institutional experience. The practice courses of the PCG departments were then designated as PCG Practice in Schools 1 (7th semester) and PCG Practice in Schools 2 (8th semester) in the Teacher Training License Programs Paper, published by the CoHE in 2017.

Brott [15] has interpreted the internship activities of school counselors in the US under the topics of; (a) individual psychological counseling, (b) group psychological counseling, (c) class guidance, (d) family education, (e) project development and implementation. Psychological counselor candidates in the US make a presentation with their portfolio including the projects they have developed and other activities during their internships to other candidates and faculty members. Preparing and presenting scientific posters about the projects are part of the psychological counselor candidate training program.

Previous studies in the literature on the evaluation of teaching practice courses mainly focus on the student opinions, and there is a significant lack of studies on professor and practice teacher opinions, which are equally important stakeholders in the field. On the other hand, despite being called teaching practice courses in the faculties of education, the contents and implementation of the teaching practice courses in PCG are considered different. Standing on these two fundamental reasons, the aim of this study is to evaluate the teaching practice course in the departments of PCG basis of student, professor of practice and practice teacher opinions. 


\section{RESEARCH METHOD}

\subsection{Research model}

This study, aiming to provide the evaluation of teaching practice courses in the PCG departments by the students, professors and practice teachers/psychological counselors, uses the phenomenological pattern in accordance with the nature of the subject. The phenomenological pattern focuses on the phenomena which we are aware of, but do not understand in a deep and detailed manner. The phenomena may have different manifestations; such as incidents, experiences, perceptions, orientations, concepts and situations. [16].

\subsection{Study group}

For qualitative studies which don't have precise standards regarding the study group size [17] the main focal point is whether the group provides the necessary amount of information to the researcher or not [18]. It is also necessary for the researchers to consider the factors of time, costs and access to resources when determining the number of participants [17]. The author grounds this study on the existence of students, professors from 3 different universities and practice teachers from 3 different schools in Istanbul together in the study group, in addition to the aforementioned factors. In this direction, the study group consists of 8 students who took the teaching practice course during the spring semester of 2018-2019 academic year, 5 professors who gave the lectures during the courses and 5 practice teachers who provided guidance for the courses. The participants were selected on a voluntary basis, in accordance with research ethics as considering anonymity and privacy of participants [19]. The demographic characteristics of the participants are shown on Table 1 , Table 2 and Table 3.

Table 1. Demographical characteristics of the participating students

\begin{tabular}{llll}
\hline Participant & Gender & Type of the Pratice School & Level of Practive School \\
\hline S1 & Female & Public & Elementary School \\
S2 & Female & Public & High School \\
S3 & Male & Private & Elementary School \\
S4 & Female & Public & High School \\
S5 & Male & Public & Elementary School \\
S6 & Female & Public & High School \\
S7 & Male & Private & High School \\
S8 & Female & Private & Middle School \\
\hline
\end{tabular}

Table 2. Demographical characteristics of the participating professors

\begin{tabular}{llll}
\hline Participant & Gender & Age & Type of the Pratice School \\
\hline P1 & Male & 40 & Public \\
P2 & Male & 51 & Private \\
P3 & Male & 47 & Public \\
P4 & Female & 36 & Private \\
P5 & Male & 40 & Public \\
\hline
\end{tabular}

Table 3. Demographical characteristics of the participating practice teacher

\begin{tabular}{llll}
\hline Participant & Gender & Age & Type of the Pratice School \\
\hline T1 & Female & 24 & Private \\
T2 & Male & 46 & Private \\
T3 & Female & 32 & Private \\
T4 & Male & 36 & Public \\
T5 & Female & 38 & Public \\
\hline
\end{tabular}

Table 1 shows the distribution of the participating students' genders and practice school types is homogenous in terms of the demonstrativeness of the research. Table 2 informs characteristics of the participating professors. As seen on Table 3, the distribution of the participating practice teachers' genders and practice school types is homogenous in terms of the demonstrativeness of the research.

\subsection{Data collection and data collection tools}

Semi-structured interview technique, which is a qualitative research technique, was utilized while gathering data for the research. In the semi-structured interview, the researcher prepares the questionnaire prior to the interview but may provide the participants (partial) flexibility by rearranging the questions $[16,20,21]$. 
The relevant literature and the MNE's Directive on Teaching Practice [10] was utilized when preparing the interview form. For finalizing the interview questions, three faculty members specialized in Department of Educational Sciences were asked for their opinion, to reach consensus on the questions directly related to the research purpose. As a result, totally 15 questions were included in the interview form for students, professors and teachers. Next, a pilot study was carried out with two students, two practice teachers and two proffesors who were not in the study group in order to find out whether the questions were clear enough. The understandability of the tailored questions was tested by asking to the study group. The questions were evaluated in terms of suitability for the purpose, understandability and functionality during this test. Robson [22] states that the value of research questions is equivalent to being a wellorganized question, determining the boundaries of the research, guidingthe research, and helping to achieve results.

\subsection{Validity and reliability}

Procedures for ensuring validity and reliability conditions in qualitative research include describing and interpreting the data and describing the situation, free from errors [23]. During interviews in this study, first of all, the participants were informed about the purpose and content of the study in order to minimize probable mistakes. The researcher further tried to improve the questionnaire's validity and reliability by asking repeated questions, making detailed citations and taking detailed analyses, descriptions and confirmations (feedback) from the participants. Voice recordings were made during the interview with the participants' permission. Once the voice recordings were confirmed by the participants, the data were converted into written documents. As a second step, as an interpretation criterion, attention was paid to convey the participants' expressions without adding any comments.

Finally, the following points are taken into account while explaining the relevant situation: the factors that cause the researcher to act unfairly were eliminated by checking whether the transcriptions seemed compliant with the voice recordings. In addition, each stage of the research process (preparation of questions, identification of the questions in the interview form, demographic data of the participants, data collectionn process and analysis of the data) were reported clearly and openly. Raw data are kept in order to determine their compliance with future research to be carried out in this area.

\subsection{Data analysis}

The data obtained from the participants were analyzed with content analysis to find out the factors that provide educational sustainability in schools. Content analysis is composed of three stages as forming the codes, categorizing the codes based on similarities, and finally data abstraction [24]. In this study, the data were analyzed in a way to first identify subcategories, followed by general categories, and finally to elicit the themes. The themes were designed considering their inclusiveness for all the answers. Other points of consideration were that the answers would fall under a single theme and the themes were independent from each other. The researcher also employed another researcher to independently carry out the same process during the research. The two researchers then came together and reached a consensus after discussing their opinions under various themes. This way, the internal validity of the research was established. For the external validity of the research, the methodology of the study was described in detail. Additionally, the inclusion of more than one researcher to the study, the clear description of the research process, the privacy of the raw data and finally, the alignment and confirmation of the research data with the researcher's personal professional observations comply with the reliability standards of qualitative research [16]. The data analyzed in this were also supported with direct citations.

\section{RESULTS AND DISCUSSION} in that order.

The findings of the study are presented below, as student, professor and practice teacher opinions,

\subsection{Findings including students' opinions on the teaching practice course}

The students' answers to the open-ended questions in the questionnaire were separately analyzed based on singular questions. For each question, first the main themes and sub themes which shape these main themes were determined. The first question asks the students about "how they planned school practices". The students' answers were gathered under 4 themes, as no planning ( $\mathrm{f}=4)$, general planning without dates $(\mathrm{f}=2)$, planning the dates to go to the school $(\mathrm{f}=1)$, planning in accordance with the directive from the school $(\mathrm{f}=1)$. The most frequent theme was found to be "no planning". 
"S2: When we first arrived, they didn't even introduce themselves to us. They made us conduct some practice, some scale which was implemented in the school. They made us evaluate it, then it was over".

The second question asks the students "which practices they actively participate in". The students' answers were gathered under 7 themes, as student sessions $(\mathrm{f}=7)$, student seminars ( $\mathrm{f}=3$ ), personal recognition techniques and scale application ( $\mathrm{f}=3$ ), file examination and arrangement ( $\mathrm{f}=3$ ), group guidance $(\mathrm{f}=3)$, parent sessions $(\mathrm{f}=3)$ and others $(\mathrm{f}=2)$. The most frequent theme is "student sessions".

The third question asks the students about "school practices they weren't allowed to participate". The answers were grouped under 3 themes, as parent sessions ( $f=5)$, student sessions $(f=3)$, parent seminars $(\mathrm{f}=2)$. The most frequent theme was "Parent sessions".

"S8: Until now, we have never been the active director or active counselor in individual sessions. This is because the institution doesn't want to take any risks".

The fourth question asks the students "if they feel as a teacher candidate in the institution where they spend their internship". The answers were grouped in 2 themes, as those feeling like a teacher candidate $(\mathrm{f}=5)$, Those not feeling like a teacher candidate $(\mathrm{f}=3)$.

"S4: I mean, they were speaking to the students in an informative way before we started the practice. Things like "Mr Ahmet is your new counselor".

"S6: I could feel like a teacher if they gave me more responsibilities on one-to-one student sessions and parent sessions".

The fiftth question asks the students about "their primary achievements in the teaching practice course". The students' answers were grouped under 7 themes, as counseling skills ( $\mathrm{f}=4)$, communication skills $(\mathrm{f}=3)$, professional awareness $(\mathrm{f}=3)$, implementing practices $(\mathrm{f}=3)$, implementing scales $(\mathrm{f}=2)$, institutional awareness $(\mathrm{f}=2)$ and other $(\mathrm{f}=4)$.

"S1: I learned how to approach people and not to panic. I am a panicky person. I learned to stay calm. I understood how to approach the kids. I need to listen to whom I am talking to, I mustn't interrupt. I need to let them speak'".

The sixth question asks the students about "the difficulties they have encountered during the teaching practice course". The answers were grouped under 3 themes as not being able to attend to the practices $(\mathrm{f}=4)$, high number of practice students $(\mathrm{f}=2)$, problems in the institutional processes $(\mathrm{f}=2)$.

"S3: It would be better if the teachers would include us to the things they do. It's better for us to see the practice. If the teacher says "do this thing for me", I would gladly do it, but they don't provide the opportunity".

"S4: I think we need to go in smaller groups. When there's too much people, the teacher blames us. Says it's because all of you are here that the students don't come".

\subsection{Findings including the professors of practice opinions on the teaching practice}

In the first question, the professors were asked about "the difficulties they encountered during the teaching practice process". Their answers were gathered under 3 themes as difficulties regarding the practice teachers $(f=4)$, difficulties regarding the system $(f=3)$ and others $(f=2)$.

"P2: The advisor teachers are unconcerned, they don't let the students take active roles in individual or group sessions".

"P5: The biggest problem, in my opinion, is that most of the students - or teacher candidates - are still taking many other courses during the teaching practice course. The students mustn't have any classes other than teaching practice during their final yea "r.

The second question asked the professors about "their suggestions on improving the teaching practice course". Their answers, as seen on as suggestions about the practice process $(\mathrm{f}=5)$ and suggestions about the MNEIS (Ministry of National Education Information System) ( $\mathrm{f}=3$ ) were grouped under 2 themes. 
"P1: It would be better if there was a practice guidebook, to draw the boundaries and state what the practice teachers shall do".

"P3: Internship durations must be increased".

"P4: Opportunities for taking internships in different institutions".

The third question asks the professors about "what they would do if they were to conduct an activity in a practice school". The answers were grouped under 3 themes as activities involving students $(\mathrm{f}=3)$, activities involving administrators and teachers $(\mathrm{f}=2)$, activities involving parents $(\mathrm{f}=2$.)

"P2: Projects involving special talented children, or projects focusing on careers, attitudes and self-knowledge for children can be done".

"P5: We would like to receive the practice teachers once or twice a semester in our faculty and arrange a contact meeting".

"P4: Seminars, or conferences on relevant topics can be held for the parents".

\subsection{Findings including the practice teachers' opinions on the teaching practice course}

In the first question, the teachers were asked about "the basic activities that they perform together with the teacher candidates". Their answers were grouped under 4 themes as individual sessions ( $\mathrm{f}=7$ ), group sessions $(\mathrm{f}=6)$, tasks involving official processes $(\mathrm{f}=4)$ and others $(\mathrm{f}=2)$.

"T2: For example, we conducted our technology addiction test with the teacher candidates".

"T5: They all went into a class and made their presentations, one by one, and I watched.

After, we talked about what to do and what not to do when exercising authority in the class".

The second question asks the practice teachers about "the practices they don't allow the teacher candidates to do". The teachers' answers are grouped under 2 themes as parent sessions $(\mathrm{f}=2)$ and student sessions $(\mathrm{f}=2)$.

"T5: I told them they cannot be there in an individual session without even asking the child".

Because they can't possibly be there during a psychological counseling session.

The third question asks the teachers about "whether they feel competent enough as a practice teacher". Their answers were gathered in two groups, as yes, I feel competent ( $\mathrm{f}=4$ ) and no, I don't feel competent $(\mathrm{f}=1)$.

“T3: Yes, I feel competent. Since I have good professional experience, I can comfortably say that I know what must be done in my job how it is done in the institutions that I have worked".

The fourth question asks the teachers about "how they maintain the cooperation with the professors of practice". The teachers' answers were grouped under the two themes as establishing cooperation $(\mathrm{f}=3)$ and failing to establish cooperation $(\mathrm{f}=2)$.

"T4: The academician never came, we weren't able to communicate. This is my side, but the other side is that the children really got it together with the change of the academician".

The fifth question asks the teachers about "what would they expect if they were given the chance to cooperate with the faculty the students come from". The answers were grouped under 3 themes as expectations about the administrators and teachers in the schools $(\mathrm{f}=4)$, expectations about the students in the schools $(\mathrm{f}=1)$, expectations about the faculty $(\mathrm{f}=1)$.

"T1: For example, I could request something supportive for our fellow teachers. Teacher trainings can be very fun".

"T2: I think inviting experienced advisor teachers would be good, they can tell about what they went through during their classes, pass on their experiences. It would be fruitful in terms of turning the lessons to practice”. 
The sixth question asks the practice teachers about "their suggestions on how to improve the teaching practice course". The teachers' answers were gathered under two the themes as process $(\mathrm{f}=4)$ and content $(\mathrm{f}=3)$.

\begin{abstract}
"T3: What did these kids do until the 4th grade? What did they see? I would expect the responsible professor to come and tell me "these kids did these until the 4th grade, they received that during the school observation class, we expect those from the practice course".
\end{abstract}

\title{
3.4. Discussion
}

In this chapter, the research findings are evaluated in a way that employs the student, professor of practice and practice teacher opinions together, and the relevant body of literature is discussed. Half of the students who took the teaching practice course state that there is no planning process in the practice schools regarding the course. Students who take the course in private schools mention that this planning cannot be done due to the nature of these schools; while the practice teachers working in public schools state that they can't cooperate with the professor of practice and they experience difficulties in planning because they don't know what is expected from them. Aksu [25], has reached the conclusions that the teachers want to see the academicians in their schools more frequently and that the professors are not involved enough with their students, in her study she has conducted with 526 teachers. It is seen that efficient communication and cooperation between the professors of practice and practice teachers are important for the teaching practice courses' efficiency [26].

The practices that are the most actively participated by the students were found to be student sessions, student seminars, individual recognition techniques, scale applications, and file examination and arrangement; while practice teachers more commonly mentioned supporting the students on individual and group sessions. On the other hand, the students didn't mention group sessions or legal processes (meetings, documents, etc.) Özyürek [27], has attempted to find out what the practices that school advisor candidates conducted are. These practices are examined under the topics of; (a) developing psychological counseling and guidance programs, (b) program evaluation and accountability practices, (c) applying psychological tests, (d) applying individual recognition techniques and (e) other practices (coordination, peer guidance, referring, consultation and orientation. According to the findings, the students perform the activities that will increase their competence in the skills under these topics insufficiently. The most practiced activities are the ones involving individual recognition techniques. This finding is parallel to the existing results.

The chief practices among the ones that the students are not allowed to participate in are parent and student sessions. Students have stated that the practice teachers do not want to take risks, especially in private schools; while practice teachers mentioned refraining from allowing the counselor candidates in the sessions particularly because that the counselee students may withdraw. However, given the importance of supervision in the training process of counselor candidates, this situation poses a serious difficulty. In psychological counseling education, it is needed to train the candidates with the help of guidelines on the subjects of education, practice, research and diversity, and set aside the traditional methods. USA and many other countries stipulate doctorate level education and up to 600 hours of supervision. The integration of academic education and internships and training psychological counselors with diverse skills carry importance. [28, 29] (Boggs \& Douce, 2000; Bowers \& Hatch, 2005). Paker [30], has reached the results that, though a great majority of teacher candidates $(91 \%)$ received feedback from the professor of practice, most of the feedbacks $(85 \%)$ were not in detail and mostly included expressions like "good, not bad, maybe better next time". Teacher candidates state that they receive feedbacks which provide no improvement to their professional development; the feedbacks do not encourage them to think analytically, improve them in observing and evaluating themselves during this process, nor contribute to their awareness for the problems they encounter. Most of the teacher candidates state feeling like a teacher candidate in the institutions that they do their internships in. Speeches like "you can do it" and more responsibilities are seen to increase this feeling, while "not being included in the parent/student sessions" decreases it. Koç and Yıldız [31] have found that school administrations and practice teachers do not provide enough support for the teacher candidates.

Findings on the communication process and cooperation between the students, practice teachers and professors of practice mainly show that WhatsApp groups are used. It is thought that this medium is used because of its fast returns. While there weren't any difficulties in the students' communication with their professors and practice teachers; it was found that the communication between the professors and practice teachers was problematic. Practice teachers have stated that they can't maintain cooperation with the professors. Teacher candidates, on the other hand, expect the other stakeholders to organize activities at the start of every term for all the parties to take part in [32]. Kılıç [33] states that the teaching practice course leaves a very positive impression on the teacher candidates; and that there is need for seminars to improve 
the level of cooperation between the faculties and practice schools; and to inform the teachers that will take part in the course. Ünver [34] has found that faculty administrators and professors have sufficient knowledge on which subjects to cooperate in teaching practices and who should act how to facilitate this cooperation. Korthagen, Loughran and Russell [35] mention the university-school cooperation in the two final principles of teacher education that they have developed. The programs that the teacher has experienced during his/her own learning process shall serve as a model in that teacher's future teaching process. Because of this, the manner which the professor conducts processes within the course gains importance. Institutions which provide teacher education and mentor teachers should cooperate to develop helpful tools that will encourage the students; and studies on the fundamental subjects of education should be made [36].

Practice students have expressed their basic achievements in the teaching practice course as; communication skills, counselling skills and professional awareness. Brott [15] states that some of the questions worth discussing in training school counsellors are "what are the qualities of an efficient psychological counsellor?", "which skills should be used against which setbacks?", and "how to tell if one is an efficient psychological counsellor?". In fact, these questions lie at the foundation of school counsellor training and program development. In USA, ASCA National Model [37] by The American School Counseling Association (ASCA) is the chosen model. A nation-wide survey in the USA [38] has found that a significant portion of psychological counsellor educators $(69 \%)$ use this model for training the next generation of school counsellors. However, this model doesn't include which activities to conduct during the internship period. The elementary and middle schools in our country have started implementing class guidance programs since 2006 [39, 40], According to this program, students between the 1st and 12th classes are subjected to guidance activities by their teachers and counsellors to provide them certain skills. Thus, taking the ASCA National Model as a base in the school counselling activities may bear benefits.

All of the study group was asked about "the difficulties that they have encountered during the teaching practice course". The students mentioned the insufficiencies of practices and the high number of practice students; the professors of practice mentioned the unwillingness of the practice teachers; and the practice teachers mentioned the high number of practice students, the neglect by the professors of practice and their lack of information about the expectations of the university as the primary difficulties. Çepni and Aydın [11] have found that the teacher candidates experience many different problems in the teaching practice courses. The problems involving school practices are not specific to a single field but are rather common problems that are experienced in other areas of school teaching.

Demir [41] has reached the conclusion in her study that the number of teacher candidates assigned to a single advisor is too much and because of this, the students can't communicate adequately with their advisors, a single advisor is not enough for them and they go to the practice schools with many shortcomings. It was found that the students experience problems in subjects like receiving preliminary information, direction, receiving feedback, and preparing reports about the practices. The candidate teachers have stated that their internship days should be set considering their schedule in the university [11]. Similarly, teacher candidates ask for their classwork load to be lightened during the internship periods [41]. Other research findings include the insufficient time for practice, insufficient feedback from the practice teachers to the interns due to the high number of interns assigned to the same practice teacher, and the inflexibility of the teaching practice course hours $[42,43]$. The crowded practice groups affect the distribution of resources negatively; and attendance by the students in the same group to the practices on different days becomes impossible because of the faculty's class schedules [44].

Teacher candidates find the practice times insufficient and expect the practice durations to be increased. They also expect the groups to consist of 1-3 people [32]. Relevant research results show parallelism with this study's findings. This study has found, dissimilarly to other studies, that professors of practice see "the unwillingness of the practice teachers" as the main difficulties; while the practice teachers mention "the high number of students", "neglect by the professors of practice" and "not knowing the expectations of the university". An important finding is that both sides have a lack of communication and don't know each other's expectations. It was found as the result of of the study that the students are happy with the attention they receive from both the school administrations and practice teachers, and they feel as a teacher in the school. Demir and Çaml [45] mention, in the study where they examine the most common problems of teaching practice courses in the practice schools, that the most common negative behaviors that the students experience are not sharing the responsibilities, not being seen as a figure of authority and neglect. Demir ve Çamlı's [45] findings contradict with the findings of this study.

The whole study group was asked about "their suggestions on how to improve the teaching practice course". The answers were seen to be tending towards "suggestions involving the practice processes" in all groups. All three groups agree that the practice durations need to be increased, and that there must be a clear guideline about the practice. In addition, the students request more practice opportunities; while professors of practice suggest detailed training programs for practice teachers. The practice teachers' suggestions include 
requests for a document explaining the previous classes that the students have taken, a full day to be assigned as the practice day and that the PCG internship practices and evaluations are differentiated from other teaching areas in the MNEIS. Parallel to this study's findings, Özpolat and Gürsoy's [5] study has found that teacher candidates' suggestions for changes in the teacher candidate training programs mainly involve the stakeholders, followed by practice, content, time and attitude. Regarding the stakeholders, the teacher candidates have stated that this training should include competent advisor teachers and lecturers, academicians should also attend these trainings, and additionally, the school principals should be better informed about this program. Gökulu [1], on the other hand, has reached the conclusion that the advisor teachers must be better informed about the process of teacher candidate training program. Değirmençay and Kasap [2] state that the guidebooks prepared by the faculties are inadequate. $21.6 \%$ of the teacher candidates mentioned not being able to successfully attend to the school experience course because of the intensity of other courses in the faculty. The percentages lead to the conclusion that the teacher candidates find their relationships with their professors in the scope of School Experience course important but think that the guidebook they use is insufficient. Moreover, the teacher candidates have stated that in order for the School Experience course to be carried out successfully, intensity of the other classes in the faculty should be reduced, and that the professors don't give the feedbacks or make the adjustments which are needed.

When the professors of practice and practice teachers are asked about how they maintained communication with each other, both groups were seen to experience difficulties in establishing communication. Practice teachers state that the professors of practice don't visit their schools; while professors mentioned the unwillingness of practice teachers. This situation is thought to reflect negatively on the cooperation of both sides and the general quality of the teaching practice course. When the parties were asked about the expectations from each other, it was revealed that the practice teachers mainly requested support on educational matters that would improve them (postgraduate programs, in service training, etc.); while the professors of practice desired to work with the practice teachers in research and development projects in the schools. It is thought that both sides would benefit, and the quality of the teaching practice courses would increase in the case where said projects are realized. Şimşek, Alkan and Erdem [46] also mentioned the need for an effective cooperation between the faculty and school personnel in their study. The researchers suggest strengthening the cooperation between the personnel of practice schools and faculties, and that configurations towards the efficiency of the teaching practice courses should be organized. When the body of literature outside of Turkey is reviewed, it is seen that universities have their own specialized teacher training programs in addition to the teacher training programs of the states. Smith and Souviney [13], who work on university based internship programs, state that these programs must be carried out with the cooperation of $\mathrm{t}$ regional executives and teacher associations. On the other hand, kind of this cooperation is also important for graduated teachers to find jobs. Brott [15] emphasizes the need for a master's degree level education in PCG. This is similar to the professional standards in the School Psychological Counselor definition of the Professional Competency Board [16]. The expectations of the practice teachers about the faculties to support postgraduate education also fall in line with these findings.

\section{CONCLUSION}

The suggestions based on the findings are given under two topics: suggestions for the decision makers and the practitioners. The suggestions for the decision makers can be summarized as; the duration of the teaching practice internship should be increased, a detailed internship guide should be prepared, the students should attend to only the practice courses during their internship, other classes in the faculty should be finished before the internship, practice teachers should be given more incentive in monetary terms, the MNEIS should be made more efficient, the evaluation items in the system should be suitable for PCG students, a payment module should be defined in MNEIS, and the education and assessment criteria for PCG practice teachers should be differentiated from other teaching areas.

Finally, suggestions for the practitioners can be summed up as; the academicians giving lecture in the teaching practice classes must be picked from people who have knowledge of and have worked in the schools, professors of practice should visit their students at least four times (first visit to be made during the first week), practice students should go to the practice schools on different days, practice teachers should be informed about the previous classes and internships of the practice students, and organizing endeavors that will improve the communication and the cooperation between the professors of practice and the practice teachers. 


\section{REFERENCES}

[1] A. Gökulu, "Prospective teachers' views about the prospective teacher training process in Turkey,", International Journal of Social Sciences and Education Research, vol. 3(1), pp. 111-123, 2017.

[2] Ş. A. Değirmençay and G. Kasap, "Pre-service teachers' opinions on school experience and teaching practice courses," Adnan Menderes University Faculty of Education Journal of Educational Sciences, vol. 4(2), pp. 47-57, 2013.

[3] M. Gültekin, "The metaphors that primary education teacher candidates use regarding curriculum," Education and Science, vol. 38(169), 2013.

[4] M. Şişman and M.B. Acat, "A study of school experiences practices and its effect on the perception of teaching profession," Firat University Journal of Social Science, vol. 13(1), pp. 235-250, 2003.

[5] E. T. Özpolat and G. Gürsoy, "A longitudinal study on pre and post service views of teacher candidates on teacher candidate training program," Pegem Journal of Education and Instruction, vol. 9(2), pp. 605, 2019.

[6] A. Ar1 and E. Kiraz, "Problems and solutions in school experience practices," III. National Science Education Symposium Proceedings, pp. 307-310, Ankara: MNE Publishing, 1999.

[7] S. Baştürk, "Prospective teachers' experiences about teaching practice course," 16th National Congress of Educational Sciences, 5-7 September, Tokat: Gaziosmanpaşa University, 2007.

[8] A. Eraslan, "A faculty-school partnership programme: prospective mathematics teachers' reflections on school practice course," Hacettepe University Journal of Education, vol. 34, pp. 95-105, 2008.

[9] Ö. F. Gökmen, "The computer education and instructional technology teacher candidates' views about teaching practice," University Journal of the Faculty of Education, vol. 11(1), pp. 96-115, 2015.

[10] Ministry of National Education, "Directive on the application of teaching students to be performed by educational students in educational institutions under the Ministry of National Education", 31666252, 14.06.2018.

[11] O. Çepni and F. Aydın, "Geography teacher candidates in the context of teaching practice problems and solutions," Turkey Social Studies Journal, vol. 2(2), pp.285-304, 2015.

[12] V. Ellis, "Impoverishing experience: The problem of teacher education in England," Journal of Education for Teaching, vol. 36(1), pp. 105-120, 2010.

[13] J. Smith and R.Souviney, "The internship in teacher education," Teacher Education Quarterly, pp.5-19.

[14] Council of Higher Education, "Guidance and psychological counseling undergraduate program," Retrieved from: https://www.yok.gov.tr/Documents/Kurumsal/egitim_ogretim_dairesi/Yeni-Ogretmen-Yetistirme-LisansProgramlari/Rehberlik_ve_Psikolojik_Danismanlik_Lisans_Programi.pdf, 2017.

[15] P. E. Brott, "Counselor education accountability: Training the effective professional school counselor," Professional School Counseling, vol.10(2), 2156759X0601000204, 2016.

[16] A. Yıldırım and H. Şimşek, "Qualitative research methods in the social sciences", Ankara: Seçkin, 2005.

[17] P. M. W. Hackett and B. Schwarzenbach, "Ethnographic cavcats," In P. M. W. Hackett (Ed.), Qualitative research methods in consumer psychology: Ethnography and culture, pp. 53-66, New York, NY, London: Routledge, 2016.

[18] A. Türnüklü, "A qualitative research technique that can be used effectively in educational studies: Interview," Journal of Educational Management in Theory and Practice, vol. 6(4), pp. 543-559, 2000.

[19] İ., Aydın, "Ethical values from research to publication in social sciences," Periodicals in Social Sciences, Proceedings of the First National Congress, 2016.

[20] U. K. Kılınç, "Grounded theory approach in social sciences," In: A.Yüksel,B. Mil. And Y. Bilim, (Eds.) Qualitative Research: Why, Why, How?, Ankara:Detay, pp.122-131, 2007.

[21] N. Karasar, Scientific research method, Ankara: Nobel, 2009

[22] C. Robson, Scientific research methods: Real world researches, Ankara: An1 Publishing, 2015.

[23] J. A. Maxwell, Qualitative research design: An interactive approach, California: SAGE Publications, 1996.

[24] S. Elo and H. Kyngäs, "The qualitative content analysis process," Journal of Advanced Nursing, vol. 62(1), pp. 107-115, 2008.

[25] M. B. Aksu, "Faculty - school collaboration seminar and evaluation of application process: Malatya province case," XIII. National Educational Sciences Congress, Malatya İnönü University, July 6-9, Proceedings Book, 2004.

[26] E. F. Şirin, H. S. Çağlayan, M. Ç. Çetin and R. Ekenler, "Opinions of prospective teachers, practice teachers and teaching staff about teaching practice activities," The International Symposium on Physical Education and Sports Teaching In Eu-Bologna Process, pp. 236-254, 2007.

[27] R. Özyürek, "Identification of the application of school counseling practices carried out by students in counseling and guidance undergraduate program," Education and Science, vol. 35(156), 2010.

[28] K. R. Boggs and L. A. Douce, "Current status and anticipated changes in psychology internships: Effects on counseling psychology training," The Counseling Psychologist, vol. 28(5), pp. 672-686, 2000.

[29] J. Bowers and Hatch, P. A. "The ASCA national model: A framework for school counseling programs," American School Counselor Association, 1101 King Street, Suite 625, Alexandria, VA 22314, 2005.

[30] T. Paker, "Problems of student teachers regarding the feedback of university supervisors and mentors during teaching practice," Pamukkale University Faculty of Education Journal, vol. 23(23), pp.132-139, 2008.

[31] C. Koç \& H.Yıldız, "The Reflectors of Teaching Experiences: Diaries," Education and Science, vol. 37(164), 2012.

[32] M. Bektaş \& A. Ayvaz, "The expectations of student teachers about teaching practice," Mersin University Journal of the Faculty of Education, vol. 8(3), pp. 209-232, 2012.

[33] D.Kıliç, "The evaluation of the effects of the teaching practice courses on teacher candidates," Journal of Atatürk University Kazım Karabekir Faculty of Education, vol. 10, 2004. 
[34] G. Ünver, "Collaboration on teaching practice: A case study," Gazi University Journal of the Faculty of Education, vol. 23(1), 2003.

[35] F. Korthagen, J. Loughran and T. Russell, "Developing fundamental principles for teacher education programs and practices," Teaching and Teacher Eucation, vol. 22(8), pp. 1020-1041, 2006.

[36] N. Helgevold, G. Næsheim-Bjørkvik and S. Østrem, "Key focus areas and use of tools in mentoring conversations during internship in initial teacher education," Teaching and Teacher Education, vol. 49, pp. 128-137, 2015.

[37] American School Counselor Association, "ASCA National Model: A framework for school counseling programs," American School Counselor Association, 2012.

[38] R. Perusse, G. E. Goodnough and C. J. Noel, "A national survey of school counselor preparation programs: Screening methods, faculty experiences, curricular content, and fieldwork requirements," Counselor Education and Supervision, vol. 40(4), pp. 252-262, 2001.

[39] S. Erkan, (Eds.) "Primary and secondary education institutions classroom guidance program. Primary activity examples", Ankara: MNE General Directorate of Special Education Guidance and Counseling Services, 2007a.

[40] S. Erkan, (Eds.) "Primary and secondary education institutions classroom guidance program. Examples of secondary education activities", Ankara: MNE General Directorate of Special Education Guidance and Counseling Services, 2007.

[41] Y. Demir, "Problems of social studies teacher candidates and their solution suggestions," Master Thesis, Abant İzzet Baysal University, Bolu, 2012.

[42] Y.Tepeli and M. Caner, "Teacher certificate program students' opinions on teaching practice", Journal of Educational Sciences Research, vol. 4(2), pp.313-328, 2014.

[43] A.Azar, "Reflections of their views on school experience and teaching practice lessons", Journal of National Education, pp.159, 2003.

[44] Ö. F. Çetin and H.Bulut, "Examining the evaluation of school experience I, II and teaching practice courses by the application teachers and prospective teachers," Erzincan University Faculty of Education Journal, vol. 4 (2), pp. 69-75.

[45] Ö.Demir and Ö.Çaml,, "Schools teaching practice lesson practice problems encountered the investigation of class and opinions of pre-school students: A qualitative study," Journal of Uludağ University Faculty of Education, vol. 24 (1), pp. 117-139, 2011.

[46] S. Şimşek, V. Alkan and A. R. Erdem, "A qualitative study about teaching practice," Pamukkale University Faculty of Education Journal, vol. 34(34), pp. 63-73, 2013. 